\title{
DIVIDEND POLICY IN NORDIC LISTED FIRMS
}

\author{
Tor Brunzell, Eva Liljeblom, Anders Löflund and Mika Vaihekoski
}

January 13, 2013

Comments are welcome.

\begin{abstract}
In this paper we analyze the results from a survey among all publicly listed Nordic firms on their dividend payout policy. A number of interesting results are found. The results show e.g. that 72 percent of the Nordic companies have a specified dividend policy. Larger and more profitable companies are more likely to have a defined dividend policy in place. The dividend policy is mostly influenced by the considerations of company's capital structure and future earnings. We get indirect support for agency / monitoring motives, or the need for a stable cash flow, rather than for the signaling motive, since the likelihood for a firm having an explicit dividend policy is positively related to ownership concentration as well as to large long-term, private or industrial owners.
\end{abstract}

KEYWORDS: $\quad$ corporate finance, dividend policy, payout, Nordic, OMX

JEL Classification: G31, M21, O16

EFMA Classification: $\quad 170$

In alphabetical order. Brunzell: Stockholm University, School of Business. E-mail: tb(at)fek.su.se. Liljeblom and Löflund: Hanken School of Economics, Department of Finance and Statistics. E-mail: eva.liljeblom(at)hanken.fi and anders.loflund(at)hanken.fi. Vaihekoski: University of Turku, Turku School of Economics. E-mail: mika.vaihekoski(at)utu.fi. We are grateful for the comments from Hanna Silvola, Frederick Lindahl, Hannu Schadewitz, and others participants at the TSE seminar. Authors wish to thank Nils Liljendahl, Kirsi Noro, Magnus Blomkvist, and Anna Björn for research assistance. Financial support from NASDAQ OMX Nordic Foundation and Academy of Finland is gratefully acknowledged. 


\section{INTRODUCTION}

Ever since studies such as Lintner (1956) and Fama and Babiak (1968), a large number of papers have over time studied corporate dividend policies (payout ratios) and factors that contribute to the payout decision. Recently, focus has been e.g. on the choice between dividends vs. share repurchases (see e.g. Jagannathan et al., 2000; Guay and Harfoord, 2000, and Skinner, 2008), the question of disappearing dividends (see e.g. Fama and French, 2001; DeAngelo et al., 2004), and the relationship between minority protection and dividends (see e.g. La Porta et al., 2000, and Faccio et al., 2001). Typically, the dividend payout is found to be function of factors such as the profitability of the company, stability of the earnings, rate of growth, free cash flows, and more recently, the governing structure of the company. In their survey of dividend policies, DeAngelo et al. (2008) conclude that a simple asymmetric information framework that emphasized both the need to distribute free cash flow, and embeds agency costs and security valuation problems, does a good job at explaining observed payout policies. They also conclude that other motives and factors such as signaling, tax preferences, and clientele demands have at best minor influences, but that behavioral biases at the managerial level (such as overconfidence) and the idiosyncratic preferences of controlling shareholders plausibly have a first order impact. ${ }^{1}$

We contribute to the literature on studies of the relationship between controlling shareholders and dividend decisions by studying the determinants of whether a firm follows a more explicit dividend policy. While implicit dividend policies (as the relationship between dividends and earnings, and the speed of adjustment to an assumed optimal level) have been subject to many studies, only a few papers have studied whether a company has an explicit defined dividend policy in place, and what factors are related to the choice of that policy (exceptions include, e.g., Brav et al., 2005). ${ }^{2}$

1 They also e.g. note that the evidence strongly supports the view that managers of mature firms behave as if they have strong implicit contracts with their stockholders not to reduce dividends opportunistically.

2 Brav et al. (2005) asked dividend payers what they attempt to target with their dividend policy, and whether the target is strict or flexible. $43 \%$ of the managers say that their dividend target is somewhat or very strict. A comparison of the results of Lintner (1956) and Brav et al. (2005) indicate that a change in the targets of a dividend policy has taken place. While Lintner (1956) reported that two thirds of the firms had a reasonable well-defined long-run payout ratio, Brav et al. (2005) report that only $28 \%$ of the respondents target dividend payout, and another $27 \%$ target growth in dividends per share. Nearly $40 \%$ 
There are many reasons for why the question of whether the firm follows a clearly defined dividend policy ${ }^{3}$ may be of interest. First, it can be seen as an alternative approach to study whether signaling can be on of the motives for dividend distributions. Without expectations for future dividends, formulated by some systematic publicly announced dividend policy, deviations from such expectations cannot be identified and reacted upon. Thus one could view a "dividend policy" as a necessary but not sufficient condition for dividends to convey information about future earnings. Secondly, a systematic, defined dividend policy may also be required by dominant corporate owners, either to solve agency problems between minority owners and large owners in firms with concentrated ownership (La Porta et al., 2000), of taxational reasons, or because large owners may be more dependent on regular dividends from the firm, and thus interested in the predictability in the dividend stream. The data used in this study is from the Nordic markets, where there is much cross-sectional variety in ownership concentration, thus providing an especially fruitful background for a study of the link between ownership and the stringency of the dividend policy. ${ }^{4}$

We contribute by providing empirical results on the existence of a dividend policy in Nordic listed firms together with some insights into what factors affect the choice of such a policy. Most notably, we study how the existence of a major shareholder impacts the decision. Our results are based on a survey conducted among Board Chairpersons of the companies listed on the Nordic stock exchanges. The results are combined with financial data on the actual characteristics and performance of firms, and data on the largest owners and their type.

target dividends per share, thirteen percent tell that they target dividend yield, while six percent of dividend-payers claim not to target dividends at all.

3 A typical example of a defined dividend policy is publicizing dividend target payout ratios in annual reports. Another way of commitment to a defined policy is to commit to disclosing dividend policy targets in materials presented in meetings with investors and analysts. Some companies may prefer not to publish their commitments to a particular dividend policy even if they, in fact, internally have a clearly defined dividend policy.

4 We focus on dividends, not share repurchases, since prior studies indicate that the motives for and timing of these two forms of corporate payout are quite different. The survey results of Brav et al. (2005) indicates e.g. that while dividend choices are made simultaneously with (or earlier than) investment decisions, share repurchase decisions are made later. The results of Jagannathan et al. (2000) indicate that dividends are used to distribute relative permanent cash-flow shocks while repurchases are related to more transient shocks. If that is the case, a long-run "payout policy", if there is such a one in place, is not likely to use repurchases as the distribution method. The results of Skinner (2008) support this in the sense that repurchases are found to be the ones that quickly adjust to earnings changes. Moreover, in the Nordic countries, share repurchases are still much less common than dividends. 
We find that that 72 percent of the Nordic companies have an explicit dividend policy. Larger and more profitable companies are more likely to have a defined dividend policy in place. The dividend policy is mostly influenced by the considerations of company's capital structure and future earnings. In estimations studying the determinants for whether a firm has an explicit dividend policy or not, we get support for agency / monitoring motives, or the need of a stable cash flow, rather than the signaling motive, since the likelihood for a firm having an explicit dividend policy is positively related to ownership concentration as well as to large long-term, private or industrial owners. We also find that the existence of a dividend policy is negatively related to the age of the chairman. Contrasting the responses to descriptive statistics for responding firms indicates a behavioral consistency between performance and responses.

The remainder of this paper proceeds as follows. The testable hypotheses are developed in the second section. The sample and survey method are discussed in section 3 . In section 4 we present the results together with discussion of their implications. A summary is given in the final section.

\section{LITERATURE REVIEW AND HYPOTHESIS DEVELOPMENT}

There are a number of papers that study what factors are used by the companies to set their dividend policies. Early results indicate that taxes play a role if taxation on capital gains and dividends differ, but if they do not differ, taxation does not play a major role (c.f., Amihud and Murgia, 1997). In addition, the profitability of the company and the stability of its earnings play a major role in the dividend policy (see, e.g., Barclay, Smith and Watts, 1995, and Gaver and Gaver, 1993). Other significant factors include, among others, company's (expected) growth rate and investment opportunities and signaling the quality of the firm's investment potential (see, e.g., Michaely, 1996; Myers, 1984, and Fama and French, 2000). Finally, La Porta et al. (1998) observe that in countries where the minority has greater protection, the companies tend to pay higher dividends. 
A dividend policy can be formulated in many ways. In Lintner (1956) study, the most common version was to use a long-run payout ratio. In such a case, current earnings are the main determinant of the current dividend, while deviations from the target represent the signaling component. Dividend per share is another potential target, and is only weakly linked to current earnings performance through the corporate history. ${ }^{5}$ Dividends may also be related to other currently observable measures such as the stock price (as when using a dividend yield as the target). Signaling is related to the existence of a dividend policy in such a way, that unless an "expected" dividend (formulated through some policy) can be determined, an "unexpected" dividend (conveying the information value) cannot be distinguished. On the other hand, the stronger and more limiting the dividend policy is, the less it leaves room for signaling. E.g. a specific payout ratio which always would be followed would leave no information value for the dividend, in excess of that already conveyed through the disclosure of current earnings.

A dividend policy can also be used as a monitoring tool to reduce free cash flows in order to reduce management agency costs associated with the separation of ownership and control which occurs in companies. La Porta et al. (2000) offer opposite predictions for dividend policy. According to the "outcome model" (La Porta et al., 2000, and Faccio et al., 2001), dividends are paid because minority shareholders force corporations to disgorge cash, thereby diminishing the agency problems associated with free cash flow. The greater the legal protection of minority shareholders, the higher the dividend paid out, all else equal. Another view on dividends is to see them as a substitute for legal protection (Easterbrook, 1984, Gomes, 2000). According to this view, firms can despite weaker shareholder protection build a reputation of good treatment of shareholders by paying out dividends. This view suggests that dividend streams would be higher in countries with weaker shareholder protection. Of these two views, the outcome model has obtained support e.g. in cross-country analyses such as in La Porta et al. (2000) for dividend policies in 33

5 I.e., historical earnings levels have defined the possible dividend per share that can be distributed (and found optimal to distribute). Companies may then have chosen to follow a dividend policy where the target is to keep that dividend level, or to grow it at some speed, given that the earnings each respective year facilitate such a policy. 
countries, and Mitton (2004) for 19 countries. Both found that dividend payout is higher is countries with higher legal protection. ${ }^{6}$

In this paper, we study the existence of a dividend policy, not dividend levels as such. Based on the signaling motive, a dividend policy might be expected to be more common in firms with dispersed ownership, since large shareholders in firms with concentrated ownership may have access to important information through other channels than dividend signals, such as board memberships. On the other hand, empirical studies do not indicate that the signaling motive is especially important for dividends (see e.g. DeAngelo et al., 2009). In firms with a large owner, the agency and monitoring motives (the need for minority protection) may dominate and drive to a more strictly formulated dividend policy, which limits the action space for the large owner(s), but also limits chances for dividend signalling. Also large owners may favor such a policy, since large owners (unless they are institutional owners such as pension funds) are typically poorly diversified, and may be in need of a regular, more predictable dividend stream from the firm. The latter case may be more marked if the large owner is a long-term one and thus does not consider selling stocks as an alternative to dividends. This leads to the following two alternative hypotheses:

H1(A): If the agency and monitoring motives, and the need for a regular income stream, dominate, then companies with a concentrated ownership (with large long-term owners) are more likely to have a specified dividend policy.

Alternative hypothesis $\mathrm{H} 1(\mathrm{~B})$ : If the signalling motive dominates, companies with a dispersed ownership are more likely to have a specified dividend policy.

\footnotetext{
Also firm level studies investigating the relationship between the degree of ownership control and dividend policy by Maury and Pajuste (2002) for Finland, Gugler and Yurtogly (2003) for Germany, and Bena and Hanousek (2005) for the Czech Republic, provide support for the outcome model. In these studies, a negative relationship between the size of the ownership stake of the largest shareholder, and the level of dividends, was obtained. Some strands of literature have also investigated the impact of the identity of the controlling owner on dividend policies of firms. Farinha's (2005) results on management ownership and dividends (various U-shaped relationships between ownership levels and dividends), and the results of Eckbo and Verma (1994) on owner-managers in Canada are examples of such. Eckbo and Verma found that for Canadian corporations, dividends are typically not paid when individual ownermanagers have majority voting control. In contrast, Maury (2006) reports for Finland that dividends are typically higher when private shareholders are in control.
} 


\section{DATA}

\subsection{The survey data}

This paper is based on the results of a questionnaire ${ }^{7}$, directed to all Chairpersons of the Board of firms in the Nordic countries (Denmark, Finland, Iceland, Norway, and Sweden). Appendix 1 of this paper lists the questions used in the survey.

The survey was conducted in two stages. In the first stage, the questionnaire was sent to the chairmen in the Nordic firms listed on the exchanges operated by the OMX (now NASDAQ OMX), i.e. in Denmark, Finland, Iceland, and Sweden. This took place in early December 2007. In the second stage, in May 2008, the questionnaire was sent to the chairmen in the firms listed at the Oslo Børs in Norway. The questionnaire was sent as a letter directed to a named respondent. The names and addresses of the chairmen were hand-collected into a database. Ultimately, the questionnaire was sent to 780 firms in total.

The respondents were promised total anonymity i.e. the responses and the respondent's identity is only available to the researchers and the results are reported only as a group. The overall response rate was $20.4 \%$, ranging from $10.3 \%$ for Norway to $29.3 \%$ for Sweden. ${ }^{8}$ The chairpersons were the most active respondents (158 responses), although the response rate was almost the same for all categories of respondents. Table 1 reports the response rates per country and category of respondents.

\subsection{Background data}

The responses were matched with background information on firm financials and ownership concentration. The financial data is collected from three sources. Our primary source is the

7 Much work was put on the optimal design of the questionnaire. Prior to the actual survey, the questionnaire was also tested on subsets of executives and like both in Sweden as well as in Finland. For more information, see Brunzell et al. (2013).

8 The response rate is typical to this kind of surveys. For example, Brav et al. (2005) had a response rate of 16 per cent in a study among selected public and private US companies, and Graham et al. (2001) had a response rate of 10.4 per cent in their recent study. 
Amadeus database. Additional items have been collected from Datastream, when not available in Amadeus. Finally, annual reports downloaded from the web have provided an additional data source in cases where information has not been available in other databases. The financials are from the last reporting year completed prior to the questionnaire was sent out, i.e. they are mainly from the year-end 2006 for Denmark, Finland, Iceland, and Sweden, and from 2007 for Norway. Year-end exchange rates have been used to convert all financials to the same currency, euro, which already was the currency of Finland. Financial data was collected not only for responding firms, but also for the whole market, to facilitate relating our sample to the whole population of the survey. Table 2 reports descriptive statistics for responding firms and the whole population, separately for financial and nonfinancial firms. ${ }^{9}$ The value of solidity is not reported for the financials due to cross-sectional differences in how it is reported (that group of firms is very heterogeneous, including e.g. listed funds or investment companies, as well as insurance companies).

Table 2 shows that our sample firms are marginally larger than the population of firms to which the questionnaire was sent. This holds for the non-financial firms (285 in our sample) for all size related variables, but for the financials only in terms of Turnover. Our nonfinancial firms are also marginally less profitable (lower Return on Assets i.e. ROA), whereas our sample of financials (67 firms in our sample) are more profitable. The differences are, however, small and not statistically significant. We therefore conclude that our sample represents the total population quite well.

Ownership data for the firms has been collected primary from Amadeus, and secondary from annual reports from the web. The Amadeus data represents the ownership situation at the time point of the survey, while data from the annual reports is from the last reporting year prior to the survey. We collected data both on the ownership share (per cent of equity) of the largest shareholder, as well as the sum of the ownership share of the five largest owners (when available). The ownership is quite concentrated in the Nordic firms, with 42

9 Many studies restrict their sample strictly to industrial firms, since financial variables such as solidity, and the value of total assets, are on a very different level for financials vs. non-financials. Since our prime focus is the responses to the questionnaire, which do not suffer from differences in measurement, we keep all respondents included. However, we include sector dummies in all models, and also control for clustered standard errors (financials vs. non-financials) in model IV. 
firms (14\%) of firms having a majority owner, controlling more than $50 \%$ of the shares, and $179(60 \%)$ having an owner controlling $20 \%$ or more of the equity.

We also tried to identify the owner type of the largest owner. The largest owner type in our sample are private investors (or families), $37.7 \%$ of the respondents coming from such firms. The other larger groups are firms owned by mutual funds or investment companies $(16.4 \%)$, other firms $(12.1 \%)$, or "activist" owners (classified as private equity firms, activist hedge funds or like) (11.4\%).

\section{RESULTS}

\subsection{Survey responses}

We asked the Chairpersons to indicate whether their company had a defined dividend policy. Two alternatives ('yes' and 'no') were given. Panel A in Table 3 shows the results. Out of the 158 responses we got from the Chairpersons, 152 provided an answer to this question. 110 companies (72.4\%) had a defined dividend policy, 42 (27.6\%) did not.

In addition, we asked the respondents to indicate the factors that are important in the formulation of the company's dividend policy. Alternatives given ranged from 1 (not important) to 5 (very important). The results are provided in Panel B of Table 3. They show that even some of those respondents, that indicated that the company does not have a defined dividend policy, answered these additional questions suggesting that the responses represent the effect of the given factors on actual the dividend decisions made, in general, even when an explicit dividend policy was not defined.

The most important factor while considering the dividend policy are the goal to maintain capital structure that allows the company to make good investments (mean reply 4.17), stability and future earnings (4.12.), sustainable change in earnings (3.85), and company's aim to follow long term payout policy (3.63). The results are mostly in line with the earlier studies, although some differences emerge due to differences in questionnaires. Brav et al. (2005) found the negative consequences of the dividend reductions, consistency with 
historic payout policy, information content of the dividends, as well as the stability of future earnings to be the most important factors for dividend policy.

The least important factors were related to the salary increases and reductions in company's employees (2.15), dividend policy of the competitors or other companies within the same sector (2.34), and satisfaction of the minority shareholders (2.59). Similar to Brav et al. (2005) we do not find taxes (2.69) or the desire to attract new investors (3.13) to be highly important drivers for the dividend policy. The chairpersons also indicated that the desire to accumulate cash at hand (for the company) is fairly important (3.34) which gives indirect evidence against the notation that they wish to pay out dividends to protect the shareholders against unwise use of excess free cash flows.

\subsection{Determinants of the existence of an explicit dividend policy}

In order to test our hypotheses, we estimate a binary model where the dependent variable gets a value of one for those companies which answered affirmatively on the question concerning an explicit dividend policy, and zero for the others. As explanatory variables in the base-case, we include financial control variables for size and profitability. We expect that a defined dividend policy is more common in larger firms, since such firms are likely to have a larger investor universe including also dividend-dependent owners. For profitability we also expect a positive sign, since a precondition for dividend distributions is that the firm can afford such ones.

In line with the results of Graham and Harvey (2001) concerning the relationship between a target equity ratio and CEO age, we include the age of the chairman, collected mainly from annual reports and complemented by various internet and press sources such as press releases at the appointment of a new chairman, and birthday interviews. We also include firm age, defined as the age reported for the firm since its foundation, collected from annual reports. We expect that older firms may be more likely to have a dividend level by tradition, and may find less need to formulate an explicit dividend policy. We also expect that older chairmen may be less used to the practice of openly conveying an explicit dividend policy to 
investors, as they according to Graham and Harvey (2001) are concerning the specification of other targets such as a target equity ratio.

In addition, we include the main variables at focus i.e. our measures for ownership concentration. First, we use Ownership_5_largest, the aggregated equity ownership percentage by the five largest owners, as an explanatory variable. According to hypothesis $1 \mathrm{~A}$, we expect that firms with more concentrated ownership are more likely to have an explicit dividend policy. We also test three dummies for specific owner categories which may be more dividend-dependent. The first of these is Owner_LT for long-term owners which may find it due to various reasons difficult to trade in the stock. Owner_LT takes the value of one if the largest owner in the firm is a state, a municipality, a foundation or a cooperative. Owner_Private is a dummy for a private owner as the largest, and Owner_INDUSTRY is a dummy for a non-financial firm as the largest owner. These dummies leave the financial owners (many of which are likely to be of a more short-term nature and can thereby if needed get a cash return either through a payout from the firm, or as a profit from selling the share) such as banks, insurance companies, and mutual funds as the residual owner class.

The tested model is, in its fullest form, is a probit model with robust standard errors specified as follows:

Div_policy_dummy $y_{i}=\beta_{0}+\beta_{1}($ Ownership concentration $)+\beta_{2}$ (Age variables)

$$
+\beta_{3} \text { (firm controls) }+\beta_{4} \text { (country \& industry dummies) }+\varepsilon_{i} \text {, }
$$

where the ownership concentration measures include the sum of the equity owned by the five largest owners (Ownership_5_largest) as well as the three dummies for the type of the largest owner (Owner_LT, Owner_Private, and Owner_INDUSTRY), the age variables include Firm_age and CM_age, the firm controls include either the logarithm of turnover or total assets, $\ln$ (Turnover) or $\ln$ (Total_Assets), as well as the return on equity $R O E$ defined as net profits over equity. As country dummies, we include the dummies for Finland, Norway, and Sweden, leaving Iceland and Denmark without a dummy. ${ }^{10}$ We furthermore

10 The results are not sensitive to including one more dummy. However, Iceland and Denmark get (once included either one by one, or jointly while leaving some other country out) get quite similar intercept 
include sectors dummies for financial and manufacturing firms. The results for different model specifications are reported in Table 4.

First, we estimate our simplest model where the dividend policy indicator is conditioned only on corporate control variables. Size is measured using the natural logarithm of the turnover (Model Ia) or of the total assets (Model Ib). Both size variables are measured in euros. The results show that the Model $\mathrm{Ib}$ fits the data better with pseudo- $\mathrm{R}^{2}$ equal to $17.86 \%$. We get the expected signs for all these control variables. In model Ib, both size and ROE are significant, indicating that an explicit dividend policy is significantly more common in larger and more profitable firms. The coefficients for the country dummies are all significant, indicating that an explicit dividend policy is significantly more common in Finland, Norway and Sweden, as compared to firms from Denmark and Iceland.

Next, we test our main hypothesis by including an ownership concentration measure. According to hypothesis 1(A), if the company has a long-term owner, and if the ownership is more concentrated, we expect to observe a defined dividend policy. The results from model IIa give support for hypothesis IA since concentrated ownership (as measured by Ownership_5_largest) significantly increases the probability of an explicit dividend policy (a $\mathrm{t}$-value of 2.15 , significant at the $5 \%$ level). The age variables, also introduced in this model, obtain the expected signs, bur are not significant.

Finally, we introduce the owner type dummies for the largest owner. The results for model III show that besides ownership concentration as such, the effect of having a large owner either from the category defined through Owner_LT significantly increases the probability for the firm of having an explicit dividend policy. Now also CM_age is significant at the 5\% level, supporting the idea that firms with older chairmen are less likely to have an explicit dividend policy.

Since of the industry dummies, the dummy for financials is typically significant (except for in model Ib), we re-estimate the probit specification of model III adjusting for clustered standard deviations according to the dummy for a financial firm. These results are reported 
in last column of Table 4 (model IV). We find that the adjustment significantly increases the significance of most of the variables of interest. Now the ownership concentration variable Ownership_5_largets loses significance, but instead all the three large owner type dummies (i.e. also Owner_PRIVATE and Owner_INDUSTRY) are significant at the $1 \%$ level.

The results in this section strongly support our hypothesis 1A, i.e. that ownership concentration / having a large non-financial owner, potentially more dependent of a stable dividend stream, significantly increases the probability for the firm of having an explicit dividend policy. This can be interpreted as supporting the agency and/or monitoring motives, or the need for cash, as a determinant for the existence of a dividend policy, rather than the signaling motive. The latter would have predicted that a dividend policy would be more likely in firms with disperse ownership, and the related need to send a signal to less informed shareholders. We also find that having an older chairman of the board significantly reduces the probability for an explicit dividend policy.

\subsection{Additional analysis}

Next, we look more in detail at differences between firms with or without an explicit dividend policy. In the specific questions concerning the factors behind a dividend policy, arguments, such a maintaining a capital structure, and stability and future earnings, obtained high scores. We will now look more in detail at the descriptive statistics for different subgroups. We focus on the two motives obtaining the highest scores in our survey (see Table 3), the motives of maintaining capital structure, or stability and future earnings.

Table 5 reports some descriptive statistics for firms from the dividend policy group (columns one and two) or the whole population (columns three or four), divided into two groups based on their responses on the first two motives in Table 3. In Panel A, we analyse whether firms responding with the highest score of 5 to the "maintaining capital structure" motive differ in terms of their solidity from the other respondents. Only non-financial firms are included in the analyses of Panel A. We find that among firms with a dividend policy, as well as in the whole group, solidity is higher for firms giving the highest score for this motive. However, the difference is significant only in the whole population of respondents. 
In Panel B, we analyse whether respondents giving the highest score for "stability and future earnings" as a motive for dividends have higher ROEs, dividend yields, or more stable dividend yields, as might be expected. We find that these expectations concerning signs hold among firms with a dividend policy, but only the difference in average ROEs is significant at the $1 \%$ level. Also in the total population, firms giving the highest score (very important) for this motive have a significantly higher return on equity. These results give some support for the perception that the behavior of the responding firms is in line with their questionnaire responses.

\section{CONCLUSIONS}

We contribute to the literature on studies of the relationship between controlling shareholders and dividend decisions by studying the determinants of whether a firm follows a more explicit dividend policy. While implicit dividend policies have been subject to many studies, only a few papers have studied whether a company has an explicit dividend policy in place.

This study can also be seen as an alternative approach to study whether signaling can be one of the motives for dividend distributions. Without expectations for future dividends, formulated by some publicly announced dividend policy, deviations from such expectations cannot be identified and reacted upon by market participants. If signaling is an important motive, the existence of a dividend policy should be more common among firms in need to convey information to owners, such as firms with dispersed ownership. If on the other hand, a systematic dividend policy is in place either to solve agency problems between minority owners and large owners, or because large long-term owners may be more dependent on regular dividends from the firm, we would expect a positive relationship between ownership concentration / large owners, and a dividend policy.

The data used in this study is from the Nordic markets, where there is much cross-sectional variety in ownership concentration, thus providing an especially fruitful background for a study of the link between ownership and an explicit dividend policy. The hypotheses are 
tested on data collected using a survey conducted among the Chairpersons of the companies listed on the Nordic stock exchanges. The survey data are combined with financial data on the actual characteristics and performance of firms, and data on the largest owners and their type.

We find that 72 percent of the Nordic companies have a specified dividend policy. Larger and more profitable companies are more likely to have a defined dividend policy in place. The dividend policy is mostly influenced by the considerations of company's capital structure and future earnings. In estimations studying the determinants for whether a firm has an explicit dividend policy or not, we get support for agency / monitoring motives, or the need of a stable cash flow, rather than the signaling motive. The likelihood for a firm having an explicit dividend policy is significantly and positively related to ownership concentration as well as to large long-term, private or industrial owners. We also find that an explicit dividend policy is less common in firms with an older chairman. Contrasting the responses to descriptive statistics for responding firms indicates a behavioral consistency between performance and responses. 


\section{REFERENCES}

Amihud, Y. and Murgia, M., 1997. Dividends, taxes, and signaling: Evidence from Germany. Journal of Finance 52(1), 397-408.

Barclay, M., Smith, C., and Watts, R., 1995. The Determinants of Corporate Leverage and Dividend Policies. Journal of Applied Corporate Finance, vol. 7:4, 4-19.

Bena, J., and Hanousek, J., 2005. Rent extraction by large shareholders: Evidence using dividend policy in the Czech Republic. Charles University, Center for Economic Research and Graduate Education, Working Paper Series 291.

Brav, A., Graham, J. R., Harvey, C. R., Michaely, R., 2005. Payout policy in the 21 st century. Journal of Financial Economics 77 (3), 483-527.

Brunzell, T., Liljeblom, E., and Vaihekoski, M., 2013. Determinants of Capital Budgeting Methods and Hurdle Rates in Nordic Firms. Forthcoming in Accounting \& Finance. Available at http://dx.doi.org/10.1111/j.1467-629X.2011.00462.X

DeAngelo, H., DeAngelo, L. and Skinner, D.J., 2004. Are dividends disappearing? Dividend concentration and the consolidation of earnings. Journal of Financial Economics 72, 425-456.

DeAngelo, H., DeAngelo, L. and Skinner, D.J., 2008. Corporate payout policy, in Foundations and Trends in Finance, Nos. 2-3, 95-287.

Easterbrook, F. H., 1984. Two-agency explanations of dividends. American Economic Review 74(4), 650-659.

Eckbo, E., and Verma, S., 1994. Managerial share ownership. voting power, and corporate dividends. Journal of Corporate Finance 1, 33-62.

Faccio, M., Lang, L.H.P., and Young, L., 2001, Dividends and expropriation. American Economic Review 91, 54-78.

Fama, E. F. and Babiak, H, 1968. 'Dividend policy: An empirical analysis'. Journal of the American Statistical Association 63, 1132-1161.

Fama, E.G., and French, K., 2001. Disappearing dividends: Changing firm characteristics or lower propensity to pay? Journal of Financial Economics 60, 3-40.

Fama, E. and French, K., 2002. Testing tradeoff and pecking order predictions about dividends and debt. The Review of Financial Studies 15, 1-33.

Farinha, J., 2005. The relationship between dividends and insider ownership in different legal systems: international evidence. Working paper, CETE, Universidade do Porto.

Gaver, J. J. and Gaver, K. M., 1993. Additional evidence on the association between the investment opportunity set and corporate financing, dividend, and compensation policies. Journal of Accounting and Economics 16, 125-160.

Gomes, A., 2000. Going public without governance: managerial reputation effects. Journal of Finance 52, 615-646. 
Graham, J. R., and Harvey, C. R., 2001. The theory and practice of corporate finance. Journal of Financial Economics 60, 187-243.

Guay, W. and Harford, J., 2000. The cash-flow permanence and information content of dividend increases vs. repurchases. Journal of Financial Economics 57, 385-416.

Gugler, K., and Yurtoglu, B.B., 2003. Corporate governance and dividend pay-out policy in Germany. European Economic Review 47, 731-758.

Jagannathan, M., Stephens, C. and Weisbach, M., 2000. Financial flexibility and the choice between dividends and stock repurchases. Journal of Financial Economics 57, 355384.

Jensen, G. R., Solberg, D. P. and Zorm, T. S. 1992. Simultaneous Determination of Insider Ownership, Debt, and Dividend Policies. Journal of Quantitative Analysis 27(2), 247-263.

La Porta, R., López de Silanes, F., Shleifer, A. and Vishny, R., 1998. Law and Finance. Journal of Political Economy 106(6), 1113-1155.

La Porta, R., Lopez-de-Silanes F., Shleifer A., and Vishny R., 2000. Agency problems and dividend policies around the world. Journal of Finance 55, 1-33.

Liljeblom, E. and Pasternack, D., 2006. Share repurchases, dividends, and executive options: the case of dividend protection. European Financial Management 12, 7-28.

Liljeblom, E. and Vaihekoski, M., 2009. Corporate Ownership and Managerial ShortTermism: Results from a Finnish Study of Management Perceptions. International Journal of Production Economics 117, 427-438.

Lintner, J., 1956. Distribution of incomes of corporations among dividends, retained earnings, and taxes. American Economic Review 46, 97-113.

Maury, B., and Pajuste, A., 2002. Controlling shareholders, agency problems, and dividend policy in Finland. Finnish Journal of Business Economics, 15-45.

Maury, B., 2006. Family ownership and firm performance: Empirical evidence from Western European corporations. Journal of Corporate Finance 12, 321-341.

Michaely, R., Thaler, R. H., and Womack, K. L., 1996. Price reactions to dividend initiations and omissions: Overreaction or drift? Journal of Finance 50(2), 573-608.

Mitton, T., 2004. Corporate governance and dividend policy in emerging markets. Emerging Markets Review 5(4), 409-426.

Skinner, D. J., 2008. The evolving relation between earnings, dividends, and stock repurchases. Journal of Financial Economics 87(3), 582-609. 
APPENDIX: The questions from the survey included in this study.

1. Does the Company have a defined dividend policy?

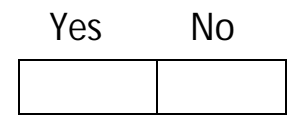

2. How important are the following factors in Your choice of Company dividends/dividend policy?

- A sustainable change in earnings

- Stability and future earnings

- The Company intends to pay a fraction of given earnings to shareholders for a long-term (given payout ratio)

- The market price of the Company's stock is enhanced by dividend yield (given dividend yield)

- Accumulate cash on hand

- Financial leverage verses equity (target company structure)

- Tax, i.e., Company shareholders pay dividend tax

- Impact from the Company's current owner

- Attract new investors

- M ethod of satisfying minority owners

- M aintain a capital structure that will allow the company to make good investments

- Dividend policy of competitors or other companies within same sector

- Salary increases/reductions of Company employees

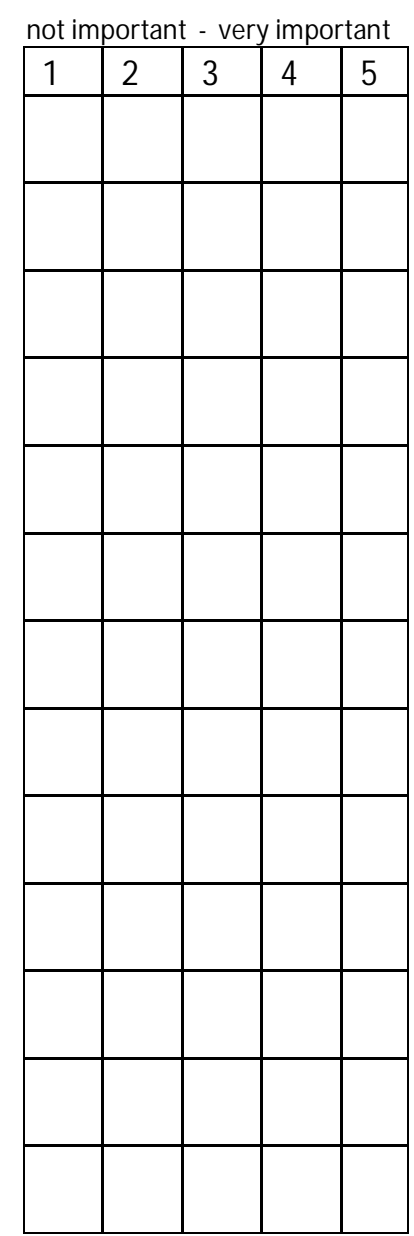




\section{TABLE 1. Descriptive statistics}

Descriptive statistics are reported for the responses received from a survey directed to the Chairmen (CMs) of all companies listed at the Nordic Stock Exchanges at the end of 2007 (except for Norway) and in May 2008 (Norway). Survey was sent to a total of 780 companies.

\section{CM}

Panel A: Number of responses

\begin{tabular}{lr}
\hline Denmark & 36 \\
Finland & 18 \\
Iceland & 4 \\
Norway & 20 \\
Sweden & 80 \\
TOTAL & 158 \\
\hline Panel B: Response rates (\%) \\
\hline Denmark & \\
Finland & $19.1 \%$ \\
Iceland & $13.8 \%$ \\
Norway & $18.2 \%$ \\
Sweden & $10.6 \%$ \\
ALL & $31.7 \%$ \\
\hline
\end{tabular}




\section{TABLE 2. Descriptive statistics for responding firms and the target population}

Descriptive statistics are reported for the listed firms in Denmark, Finland, Iceland, Norway and Sweden that were targeted in the survey (the "Population", 780 firms). We also report statistics for the responding firms (the "Sample", 352 firms) from which firms we received a filled-in questionnaire from at least one respondent. The firms are divided into Financials (banks, investment and insurance companies) and Nonfinancials based on the sector codes used by the OMX exchanges and Oslo Børs (both use the same ten categories). We report averages, medians, standard deviations, and the number of firms for which the financial information item has been obtained ("Obs") for the following variables: Turnover (in 1000s of euros), No. of employees, Total assets (in 1000s of euros), Return on total assets (ROA, defined as Net Profit to Total Assets) and Solidity (defined as Equity to Total Assets). The financial data applies to the last available reporting year prior to the date that the questionnaire was sent out (typically 2007 for Norway and 2006 for the others). The data was collected from Amadeus, Datastream, and annual reports for the companies.

\section{Non-financials}

\section{Financials}

\begin{tabular}{|c|c|c|c|c|c|}
\hline & & Sample & Population & Sample & Population \\
\hline Firms & & 285 & 615 & 67 & 165 \\
\hline \multirow{4}{*}{$\begin{array}{l}\text { Turnover, } \\
\text { 1000 EUR }\end{array}$} & Mean & 1280296 & 1058814 & 736835 & 543775 \\
\hline & Median & 106970 & 101826 & 94865 & 53981 \\
\hline & St. dev. & 4675704 & 3939259 & 1946139 & 2039941 \\
\hline & Obs & 280 & 604 & 57 & 142 \\
\hline \multirow{4}{*}{$\begin{array}{l}\text { Number of } \\
\text { employees }\end{array}$} & Mean & 4539 & 4405 & 1494 & 1520 \\
\hline & Median & 482 & 396 & 190 & 135 \\
\hline & St. dev. & 16653 & 22460 & 4403 & 4679 \\
\hline & Obs & 272 & 569 & 59 & 139 \\
\hline \multirow{4}{*}{$\begin{array}{l}\text { Total assets, } \\
1000 \text { EUR }\end{array}$} & Mean & 1285241 & 1049915 & 12054523 & 12379270 \\
\hline & Median & 107249 & 102364 & 690387 & 570934 \\
\hline & St. dev. & 4562082 & 3696905 & 48051720 & 53042764 \\
\hline & Obs & 285 & 615 & 67 & 165 \\
\hline \multirow{4}{*}{$\begin{array}{l}\text { ROA, } \\
\text { percent }\end{array}$} & Mean & 4.13 & 4.22 & 6.86 & 5.95 \\
\hline & Median & 7.34 & 6.40 & 3.88 & 2.40 \\
\hline & St. dev. & 17.61 & 16.28 & 9.18 & 9.64 \\
\hline & Obs & 283 & 613 & 67 & 162 \\
\hline \multirow{4}{*}{$\begin{array}{l}\text { Solidity, } \\
\text { percent }\end{array}$} & Mean & 47.72 & 49.07 & & \\
\hline & Median & 45.43 & 45.58 & & \\
\hline & St. dev. & 19.35 & 20.11 & & \\
\hline & Obs & 282 & 610 & & \\
\hline
\end{tabular}




\section{TABLE 3. Dividend policy}

Chairmen were asked whether the company has a defined dividend policy. Then they were asked to indicate the degree to which the given factors are of importance in their choice of dividend policy. Answers were given on a scale from one (not important) to five (very important). Panel A reports the results about the existence of the policy. Panel B reports the results for the factors influencing the dividend policy sorted from the most important to least ones. Note that the factor names have been shortened for this table (original wording and the order in the questionnaire can be seen from the Appendix). $N$ and $N_{\text {empty }}$ are the total number of respondents with non-empty or empty reply, respectively.

\begin{tabular}{|c|c|c|c|c|c|c|}
\hline & & $\mathbf{N}$ & Yes & No & & $\mathbf{N}_{\text {Empty }}$ \\
\hline \multicolumn{7}{|c|}{ Panel A: Dividend policy } \\
\hline \multirow[t]{2}{*}{ All } & $\mathrm{N}$ & 152 & 110 & 42 & & 5 \\
\hline & $\%$ of all & & $72.4 \%$ & $27.6 \%$ & & \\
\hline \multicolumn{2}{|c|}{ Panel B: Factors } & $\mathbf{N}$ & Mean & Median & Std. dev. & $\mathbf{N}_{\text {Empty }}$ \\
\hline \multicolumn{2}{|c|}{ Maintain capital structure } & 140 & 4.17 & 4 & 0.85 & 4 \\
\hline \multicolumn{2}{|c|}{ Stability and future earnings } & 139 & 4.12 & 4 & 0.89 & 4 \\
\hline \multicolumn{2}{|c|}{$\begin{array}{l}\text { Sustainable change in } \\
\text { earnings }\end{array}$} & 134 & 3.85 & 4 & 0.96 & 4 \\
\hline \multicolumn{2}{|c|}{$\begin{array}{l}\text { Firms intends to follow long- } \\
\text { term payout policy }\end{array}$} & 142 & 3.63 & 4 & 1.25 & 4 \\
\hline \multicolumn{2}{|c|}{ Target capital structure } & 133 & 3.49 & 4 & 1.00 & 4 \\
\hline \multicolumn{2}{|c|}{ Accumulate cash on hand } & 135 & 3.34 & 3 & 1.08 & 3 \\
\hline \multicolumn{2}{|c|}{ Attract new investors } & 136 & 3.13 & 3 & 1.08 & 3 \\
\hline \multicolumn{2}{|c|}{ DY enhances stock price } & 131 & 3.02 & 3 & 1.12 & 3 \\
\hline \multicolumn{2}{|c|}{ Impact from the Owner } & 133 & 2.91 & 3 & 1.16 & 3 \\
\hline \multicolumn{2}{|c|}{ Taxes } & 133 & 2.69 & 3 & 1.14 & 3 \\
\hline \multicolumn{2}{|c|}{ Satisfy minority owners } & 127 & 2.59 & 3 & 1.08 & 3 \\
\hline \multicolumn{2}{|c|}{$\begin{array}{l}\text { Dividend policy of } \\
\text { competitors }\end{array}$} & 135 & 2.34 & 2 & 1.05 & 2 \\
\hline \multicolumn{7}{|c|}{ Salary increases } \\
\hline \multicolumn{2}{|c|}{ /employment } & 131 & 2.15 & 2 & 1.05 & 2 \\
\hline
\end{tabular}




\section{TABLE 4. Determinants for the existence of a specified dividend policy}

The table reports first the results for the estimation of probit-models, where the dependent variable is a dummy with a value of one when a company's chairperson indicated that the company has a defined dividend policy, and zero otherwise. The explanatory variables are: a constant, ; the natural logarithm of turnover, the natural logarithm of total assets, net profit over equity $(R O E)$, the aggregated ownership percentage by the 5 largest owners, dummies for owner type (Owner_LT for long-term, potentially dividenddependent owners: a state or municipality, a foundation, or a co-operative as an owner; Owner_PRIVATE for a private owner, and Owner_INDUSTRY for an industrial one), firm age, the age of the chairman,, and three country dummies (for Finland, Sweden, and Norway, leaving Denmark and Iceland without a dummy). All models include sector dummies for industrial (manufacturing) and financial firms. Robust standard errors, and standard errors adjusted for clusters (a financial / nonfinancial firm) have been used. * $(* *)$ denotes significance at the $10 \%(5 \%)$ levels, one-sided tests. The Wald $\mathrm{Chi}^{2}$, its prob value, and the pseudo- $\mathrm{R}^{2}$ are also reported when available.

\begin{tabular}{|c|c|c|c|c|c|}
\hline Explanatory variables & Model Ia & Model Ib & Model II & Model III & Model IV \\
\hline Constant & $\begin{array}{l}-2.1582 \\
-1.94^{*}\end{array}$ & $\begin{array}{l}-2.5414 \\
-2.76 * *\end{array}$ & $\begin{array}{l}-2.7900 \\
-2.16^{*}\end{array}$ & $\begin{array}{l}-2.4556 \\
-1.80 * *\end{array}$ & $\begin{array}{l}-2.4556 \\
-2.73 * *\end{array}$ \\
\hline $\ln ($ Turnover $)$ & $\begin{array}{l}0.1850 \\
2.01 *\end{array}$ & & & & \\
\hline $\ln ($ Total_Assets) & & $\begin{array}{l}0.2029 \\
2.75 * *\end{array}$ & $\begin{array}{l}0.2830 \\
3.22 * *\end{array}$ & $\begin{array}{l}0.2791 \\
3.06 * *\end{array}$ & $\begin{array}{l}0.2791 \\
3.97 * *\end{array}$ \\
\hline$R O E$ & $\begin{array}{l}0.0037 \\
1.41\end{array}$ & $\begin{array}{l}0.0054 \\
1.74 *\end{array}$ & $\begin{array}{l}0.0057 \\
1.80^{*}\end{array}$ & $\begin{array}{l}0.0067 \\
2.00 *\end{array}$ & $\begin{array}{l}0.0067 \\
6.46^{*}\end{array}$ \\
\hline Ownership_5_largest & & & $\begin{array}{l}0.0140 \\
2.15^{*}\end{array}$ & $\begin{array}{l}0.0123 \\
1.80^{*}\end{array}$ & $\begin{array}{l}0.0123 \\
1.63\end{array}$ \\
\hline Owner_LT & & & & $\begin{array}{l}1.4886 \\
2.09^{*}\end{array}$ & $\begin{array}{c}1.4886 \\
17.43^{*}\end{array}$ \\
\hline Owner_PRIVATE & & & & $\begin{array}{l}0.5059 \\
1.62\end{array}$ & $\begin{array}{l}0.5059 \\
3.22 * *\end{array}$ \\
\hline Owner_INDUSTRY & & & & $\begin{array}{l}0.2647 \\
0.68\end{array}$ & $\begin{array}{l}0.2647 \\
3.93 * *\end{array}$ \\
\hline Firm_age & & & $\begin{array}{l}-0.0035 \\
-0.70\end{array}$ & $\begin{array}{l}-0.0037 \\
-0.73\end{array}$ & $\begin{array}{l}-0.0037 \\
-0.93\end{array}$ \\
\hline CM_age & & & $\begin{array}{l}-0.0211 \\
-1.39\end{array}$ & $\begin{array}{l}-0.0306 \\
-1.97 *\end{array}$ & $\begin{array}{l}-0.0306 \\
-3.35^{*}\end{array}$ \\
\hline Finland & $\begin{array}{l}1.2297 \\
2.33 * *\end{array}$ & $\begin{array}{l}1.4040 \\
2.70 * *\end{array}$ & $\begin{array}{l}1.4907 \\
2.60 * *\end{array}$ & $\begin{array}{l}1.6147 \\
2.76^{* *}\end{array}$ & $\begin{array}{l}1.6147 \\
5.20 * *\end{array}$ \\
\hline Norway & $\begin{array}{l}1.1273 \\
2.26 * *\end{array}$ & $\begin{array}{l}1.0739 \\
2.35^{*}\end{array}$ & $\begin{array}{l}0.8880 \\
1.84 * *\end{array}$ & $\begin{array}{l}1.0010 \\
1.96^{*}\end{array}$ & $\begin{array}{c}1.0010 \\
15.45^{*}\end{array}$ \\
\hline Sweden & $\begin{array}{l}0.5400 \\
1.81^{*}\end{array}$ & $\begin{array}{l}0.6821 \\
2.38 * *\end{array}$ & $\begin{array}{l}0.7380 \\
2.46^{* *}\end{array}$ & $\begin{array}{l}0.8154 \\
2.48 * *\end{array}$ & $\begin{array}{l}0.8154 \\
2.70 * *\end{array}$ \\
\hline Sector dummies & Included & Included & Included & Included & Included \\
\hline Clustered st.dev. & No & No & No & No & Yes \\
\hline Obs $(\mathrm{N})$ & 142 & 147 & 143 & 143 & 143 \\
\hline $\begin{array}{l}\text { Wald Chi } 2 \\
\text { Prob }\end{array}$ & $\begin{array}{l}26.76 \\
0.0004\end{array}$ & $\begin{array}{r}31.35 \\
0.0001\end{array}$ & $\begin{array}{l}32.72 \\
0.0003\end{array}$ & $\begin{array}{r}35.44 \\
0.0007\end{array}$ & $\begin{array}{l}\text { n.a. } \\
\text { n.a. }\end{array}$ \\
\hline Pseudo $\mathrm{R}^{2}$ & 0.1750 & 0.1783 & 0.2252 & 0.2635 & 0.2635 \\
\hline
\end{tabular}




\section{Table 5. Descriptive statistics for dividend policy subgroups}

The table reports descriptive statistics for different subgroups of firms answering the questionnaire's questions concerning the two most popular motives for dividends, those of maintaining capital structure (Panel A) and stability and future earnings (Panel B). In Panel A, average solidity (equity to total assets) is reported for the various subgroups, however only including non-financial responding firms. In Panel B, average ROE, dividend yield for the year closest to the questionnaire time-point, as well as the standard deviation in dividend yields for the 3 years surrounding the time-point for the questionnaire are reported. The $\mathrm{t}$-values come from tests of group differences assuming unequal variances. $*(* *)$ denotes significance at the $10 \%(5 \%)$ levels, one-sided tests.

\begin{tabular}{|c|c|c|c|c|}
\hline Dividend policy & \multicolumn{2}{|c|}{ Firms with an explicit dividend policy } & \multicolumn{2}{|c|}{ All answering firms } \\
\hline $\begin{array}{l}\text { Panel A. } \\
\text { Maintaining } \\
\text { capital structure }\end{array}$ & $\begin{array}{l}\text { Questionnaire } \\
\text { response }<5\end{array}$ & $\begin{array}{l}\text { Questionnaire } \\
\text { response }=5\end{array}$ & $\begin{array}{l}\text { Questionnaire } \\
\text { response }<5\end{array}$ & $\begin{array}{c}\text { Questionnaire } \\
\text { response }=5\end{array}$ \\
\hline Average solidity & 44.7928 & 47.2253 & 44.5570 & 52.1876 \\
\hline t-value for diff. & \multicolumn{2}{|c|}{1.13} & \multicolumn{2}{|c|}{$3.64 * *$} \\
\hline $\begin{array}{l}\text { Panel B. Stability } \\
\text { and } \\
\text { earnings }\end{array}$ & $\begin{array}{l}\text { Questionnaire } \\
\text { response }<5\end{array}$ & $\begin{array}{l}\text { Questionnaire } \\
\text { response }=5\end{array}$ & $\begin{array}{l}\text { Questionnaire } \\
\text { response }<5\end{array}$ & $\begin{array}{c}\text { Questionnaire } \\
\text { response }=5\end{array}$ \\
\hline Average ROE & 18.8803 & 23.6013 & 10.1168 & 15.7954 \\
\hline t-value for diff. & \multicolumn{2}{|c|}{$3.49 * *$} & \multicolumn{2}{|c|}{$5.23 * *$} \\
\hline Dividend yield & 3.3965 & 3.4474 & 2.6231 & 2.4177 \\
\hline t-value for diff. & \multicolumn{2}{|c|}{0.04} & \multicolumn{2}{|c|}{-0.18} \\
\hline $\begin{array}{l}\text { Average st.dev. of } \\
\text { dividend yield }\end{array}$ & 2.1773 & 1.6293 & 2.1332 & 1.7053 \\
\hline $\mathrm{t}$-value for diff. & \multicolumn{2}{|c|}{-0.59} & \multicolumn{2}{|c|}{-0.46} \\
\hline
\end{tabular}

